Journal of Social and Development Sciences

Vol. 2, No. 3, pp. 104-110, Sep 2011 (ISSN 2221-1152)

\title{
Female Labor Force Participation in Pakistan: A Case of Punjab
}

\author{
Safana Shaheen, Maqbool Hussain Sial, Masood Sarwar Awan* \\ Department of Economics, University of Sargodha, Pakistan \\ *awan811@hotmail.com
}

\begin{abstract}
The present study is an effort to investigate the patterns of female labor force participation in case of Pakistan. In particular, the study analyzed the determinants of female labor force participation decision. The study utilized Multiple Indicator Cluster Survey 2007-08 data of Punjab. Education is used as a direct human capital variable while; age is a proxy of human capital. The variables used in the analysis are female labour force participation, age, age square, marital status, area, female monthly income, family monthly income, family size, household head education, different classes of female education and employment status. To remove the selectivity bias, the study used Heckman's (1979) two step procedure. Results of Logit model depicts that household head education, primary, middle, matric \& mudrassa education level negatively related with the decision of female labor force participation while, decision towards participation is strong if female belonged to urban area, if she is married, if she has higher education, and if she has large family size. By using ordinary Least Square Method we estimated the earning function. Coefficient of age shows a substantial increase in the wages with each additional year spent. The sign of age square is negative which is according to our expectation and implying the concavity of earning function. Moreover, as the level of education increase the returns to each year of education also increases. In different occupational status females earns more if they are employee, employer or self employed than labourer (a reference category); while female earns less if they belonged to agricultural sector or other sectors than labourer. Married females earn more than others. The respondents' belonged to urban areas earn more than rural respondents. Moreover, household head education and family size are positively significantly related with female earnings.
\end{abstract}

Key words: female labour force participation, Earnings, Punjab.

\section{Introduction}

Women's decision about participation in labor market is of critical importance in determining living standard, dependency burden and saving pattern in households. Women constitute about half of the total population in Pakistan. But in Pakistan mostly women's work takes place in non-market activities in the home or the informal sector. In recent past women contribution in modern sector activities has been increasing. Factors determining the employment of women are extremely complex. At the individual level women's decision to work is subject to such factors as the availability of jobs, education level and skills. At the aggregate level female labor force participation is largely determined by the factors that are indicative of economic, social and demographic circumstances of the locality under consideration. Women are induced to participate in the labor market by the push and pull factors. The push factors mainly represent financial pressure. Women from the poorest families are pushed into the labor market due to severe economic necessity (Kazi \& Raza, 1986). Particularly, in a society divided by income groups, women belonging to lower income classes are more likely to participate in the labor market. A high family income might greatly reduce the necessity of augmenting income by involving women in the labor force. The pull factors are such attributes that create demand for labor and include the level of education, training and experience.

Neoclassical economists consider education to be one of the key determinants of women's entering the labor market. The higher the education level, the greater is women's participation in the labor market (Becker, 1965; Mincer, 1980). Furthermore, socio-economic characteristics like education might make certain jobs more available to them. Investment in human capital such as experience and on-the-job training enhance productivity, which in turn leads to higher labor earnings (Mincer \& Polachek; 1974). Demographic factors 
like age and family size are also considered to be important in affecting the labor force participation rates of the women. It has been observed that large family size and dependency burden might push mothers into the labor force. Other variables like family structure and education level of husband and parents can also be considered as potential determinants constraints on women's work participation. Some of the other factors that could influence women's participation in the labor force include availability of jobs, occupation and the distance from the possible place of work.

The present study is an attempt mainly to analyze the patterns of labor force participation among women. In particular, the study explores the determinants of women's labor force participation decision, their wage rates. In the present study we focused mainly on households' structures reflecting their socio-economic characteristics. To meet the objectives of the study utilized Multiple Indicator Cluster Survey 2007-08 data of Punjab.

The rest of study is organized as: Section two presents the review of literature, section three discusses variables and data sources and methodology, section four investigates and interprets the empirical results, and finally section five gives the conclusion of the study and also provides some policy implications.

\section{Literature Review}

Faridi et al. (2011) by using the data of Bahawalpur (district of Punjab, Pakistan), found that women's self employment is positively related with age and experience. Analysis of various education level shows that women's who have low level education highly tends towards self employment than women's who have high level of education. Moreover, women's self employment is positively related with husband wage, household assets, and number of children while; location, number of dependents and per capita income reduce women's self employment chances. Faridi et al. (2009) by using the data of Bahawalpur (district of Punjab, Pakistan), found that educational attainment levels turn out to be very significant determinant. Female's labour force participation rises with increasing level of education. Presence of children in early age groups reduces the female labour force participation.

Abe and Oishi (2008) used National Survey of Family Income and Expenditure of Japan from the period of 1994 and 2004 to investigate the earnings inequality for married women. Results show a decrease in inequality between 1993 and 2003, mainly because the average earnings of married women increased, and thus the earnings differential between high-earning women and all married women narrowed. Raaum et al. (2007) found that rich married women who have children and husband reduced their supply of labour in US and UK than Nordic countries. The study used intergenerational data of five countries UK, Denmark, Norway, US and Finland. This study put emphasis to highlight the role of marital status and sex on intergenerational earnings mobility for UK, Denmark, Norway, US and Finland. In cases of own wage effect the results show a uniform mobility of married women in all the countries but in cases of family earnings the intergenerational mobility is high in Nordic countries than for UK and US.

Ahmad and Hafeez (2007) found that the education level and economic duress are imperative reasons that influence women's labour force participation choice. By using the data of married women of Mandi Bahauddin (Northern District of Punjab, Pakistan) the study found that Human capital variables significantly affect women's earnings rates and working hours are determined by institutions. Ejaz (2007) used Pakistan Social and Living Standards Measurement Survey, 2004-05 and found that age, educational attainment and marital status have significant and positive effects on female labor force participation. Results investigate that women belong to the nuclear family and have access to vehicles, they are more likely are they to participate in economic activities, whereas a large number of children and the availability of home appliances reduces the probability of female labor force participation. Blau and Kahn (2006) by using March Current Population Survey (CPS) data from 1980-2000 of US, found that due to decrease in husband's wage during 1980s married women's labor supply function tends towards right. Results show that during 1980 and 2000 wage elasticity of women decrease by 50-56 percent and cross wage decrease by 38-47 percent. 
García-Escribano (2004) by using Panel Study of Income Dynamics of US from 1975-1999, found that presence of liquidity constraints and transitory shocks to husband's income increase female labour participation. Moreover, these factors also increase female working hours. By using an instrumented crosssectional variance decomposition the study shows a substitution effect between the female labour force participation and shocks to husband's earnings. Naqvi and Shahnaz (2004) by using Pakistan Integrated Household Survey of Pakistan from 1998-99, made an attempt to explore the factors which influence women's decision regarding work participation and concluded that age and education were positively related to decision making and participation in economic activities but married women were less likely to participate.

Maglad (1998), by using demographic survey of Sudan from the period of 1990-91, found that education is positively significantly related with female wage growth and their decision to enter for work in market. Moreover, female labour force participation is positively related with own wage and negatively related with spouse's wage, assets, and having small children. Amin (1994) by using 1992 Household Survey of Bangladesh, found that female labour force participation is inversely related with the income, purdah and patriarchal system, while female preferences to work is positively related with marital status, education and age. Georgellis and Wall, 2004; Do Trang, 2008; Le Anht, 2000; and Blanch flower provided very informative studies on the issue of the self-employment. They concluded that education, health, experience family background, marital status turned out to be very significant factors.

\section{Methodology}

The study used Multiple Indicator Cluster Survey for Punjab 2007-08. This data set gives complete information about household characteristics as well as earnings, occupation sector etc. First round of survey was conducted in 2003-04 and second round was completed in 2008. The survey was conducted by the Bureau of Statistics, Government of Punjab, Planning and Development Department with technical support of The United Nations Children's Fund (UNICEF). MICS 2007-08 consists of more than 70 indicators, which were 40 in MICS 2003-04, and the coverage has been extended down to tehsil level. The survey covered 6,368 clusters and 91,280 households in urban and rural areas of the Punjab province.

This study used the variable education which captures the direct human capital effect and age as a proxy of human capital. We have used age as proxy of human capital because in MICS data set there is no data regarding school starting age. One possible solution of this problem is to set the school starting age as six years but we have no continuous data on education. Moreover, we drop the unemployed and unpaid family helper for our analysis because the focus of this study is to investigate the determinants of personal earnings. The study used gender, age, age square, marital status, area, different classes of education, employment status, family size, household head education level, female income, family income, and female labour force participation (FLFP). The detailed descriptions of the variables are as follow.

Age $=$ age of the respondent in years.

Age square $=$ square of the age of the respondent in years.

Gender $=$ dummy variable, which is equal to 1 if respondent is male 0 for female.

Marital Status = dummy variable, which is equal to 1 if respondent is married and 0 otherwise.

Area $=$ dummy variable, which is equal to 1 if respondent belongs to all urban area 0 for rural areas.

FLFP = dummy variable, which is equal to 1 for workers and 0 for non-workers.

Family size $=$ Total number of family members.

Family Income $=$ Family monthly income.

Female Earning $=$ Female monthly income,

Household Head Education = Education level of household head.

Education 1 = dummy variable, which is equal to 1 if respondent's education level is Primary and 0 otherwise. Education 2 = dummy variable, which is equal to 1 if respondent's education level is Middle and 0 otherwise. Education 3 = dummy variable, which is equal to 1 if respondent's education level is Matric and 0 otherwise. Education $4=$ dummy variable, which is equal to 1 if respondent have higher educated degree and 0 otherwise. 
Education 5 = dummy variable, which is equal to 1 if respondent have Mudrassa degree and 0 otherwise. Employment 1 = dummy variable, which is equal to 1 if respondent is employee and 0 otherwise.

Employment 2 = dummy variable, which is equal to 1 if respondent is employer and 0 otherwise.

Employment $3=$ dummy variable, which is equal to 1 if respondent is self employed and 0 otherwise.

Employment $4=$ dummy variable, which is equal to 1 if respondent is laborer and 0 otherwise.

Employment $5=$ dummy variable, which is equal to 1 if respondent belong to Agricultural sector and 0 otherwise.

Employment 6 = dummy variable, which is equal to 1 if respondent belong to other sectors ${ }^{1}$ and 0 otherwise.

Since we do not scrutinize non-participants' wages/earnings. We faced the dilemma of sample selection bias. To remove the selectivity bias, the study used Heckman's (1979) two step procedure for the estimation of participation, earning equation. A decision to labour force participation is estimated in first step through Logit model and inverse Mill's ratio is estimated. Then in the second step the earning functions are estimated by using the inverse Mill's ratio as an additional explanatory variable.

This method generates reliable estimations of regression parameters. We denote the binary dependent variable, having value is equal to 1 if women participate in labour market and 0 otherwise, by Z. The column vector of explanatory variables is shown as $\mathrm{W}$ and the row vector of the corresponding regression parameters by $\beta$.

The density function of a normal standardized variable is shown by $f(x)$. For observation index we use subscript $i$. The following model is used for the determination of female labour force participation.

Linear probability model is $Z_{i}=\beta W_{i}+\alpha_{i} \ldots \ldots$ (1)

Normal probability model is $Z_{i}=\int_{-\infty}^{\infty W_{i}} f(x) d x+\propto_{i} \ldots \ldots$ (2)

Logit model is $Z_{i}=\frac{1}{1+e^{-x W_{i}}}+\infty_{i} \ldots .$. (3)

There may be a number of economic and social factors leading women to decide whether to enter in the labour market or not. The explanatory variables are gender, age, age square, different classes of age, marital status, area, different classes of education, employment status, family size, household head education level, and family income.

To find out the women's earning structure the study used Mincer and Polachek (1974) earning function.

$\ln M E_{i}=\beta W_{i}+\delta_{i} \ldots . .(4)$

In above specification the lnME is monthly earnings of $i$ worker in terms of natural log. $W_{i}$ is the vector of the observations $i$ on independent variables affecting the wage rate and $\beta$ the vector of the corresponding regression parameters.

\section{Findings of the Study}

It appears that the most important factors affecting the female labour force participation decision, either positively or negatively are the level of education, age, region, household head education, family size, and marital status. Household head education, education level (primary, middle, matric \& mudrassa) negatively related with the decision of female labour force participation whereas, female converge towards labour force; if she belonged to urban area, if she is married, and if she has higher education. The classes of different employment status show that female decision towards labour force participation is strong, when we use the employment status category labourer, as a reference category.

\footnotetext{
${ }^{1}$ Rental income, Profit from deposits/shares, Pension, Tutor, Embroidery/stitching, Student labourer, Labourer student, Home-based work/cottage.
} 
Table 1: Estimated Probability Model for FLFP by Different Education and Employment Groups

\begin{tabular}{llll}
\hline Variables & Coefficients & Std. Error & Sig. Level \\
\hline Constant & -0.571 & 0.101 & 0.000 \\
Age & 0.047 & 0.005 & 0.000 \\
Area & 0.077 & 0.018 & 0.000 \\
Household head education & 0.068 & 0.006 & 0.000 \\
Family size & 0.017 & 0.001 & 0.000 \\
Marital status & 0.181 & 0.008 & 0.000 \\
Education 1 (Primary) & -0.291 & 0.025 & 0.000 \\
Education 2 (Middle) & -0.232 & 0.030 & 0.000 \\
Education 3 (Matric) & -0.176 & 0.029 & 0.000 \\
Education 4 (Higher) & 0.115 & 0.031 & 0.000 \\
Education 5 (Mudrassa) & -0.042 & 0.203 & 0.835 \\
Employment 1 (Employee) & 6.498 & 0.143 & 0.000 \\
Employment 2 (Employer) & 5.243 & 0.235 & 0.000 \\
Employment 3 (Self Employed) & 2.240 & 0.349 & 0.000 \\
Employment 5 (Agriculture) & 4.504 & 0.112 & 0.000 \\
Employment 6 (others) & 6.097 & 0.129 & 0.000 \\
Cox \& Snell R square & 0.228 & & \\
\hline
\end{tabular}

By using OLS method we estimated the earning function, which depicts that the coefficient of age shows a substantial increase in the wages with each additional year spent. The sign of age square is negative which is according to our expectation and implying the concavity of earning function. Among the different levels of education the female having higher degrees earn more as compared to the respondent having education less than primary level. As the level of education increase the returns to each year of education also increases. In different occupational status females earn more if they are employee, employer or self employed than laborer; while females earn less if they belonged to agricultural sector or other sectors than labourer. Married females earn more than others. The respondent's belonged to urban areas earn more than rural respondents. Moreover, household head education and family size are positively significantly related with female earnings. The regression coefficient of inverse Mills ratio is statistically significant which shows a systematic selectivity bias is present due to censoring of non-working women from the sample.

Table 2: Earning Patterns in Different Education and Employment Groups

\begin{tabular}{llll}
\hline Variables & Coefficients & Std. Error & Sig. Level \\
\hline Constant & 8.135 & 0.074 & 0.000 \\
Age & 0.007 & 0.003 & 0.045 \\
Age $^{2}$ & -0.001 & 0.011 & 0.852 \\
Area & 0.013 & 0.018 & 0.219 \\
Household head education & 0.092 & 0.004 & 0.000 \\
Family income & 0.008 & 0.002 & 0.001 \\
Marital status & 0.001 & 0.005 & 0.791 \\
Education 1 (Primary) & 0.043 & 0.017 & 0.009 \\
Education 2 (Middle) & 0.064 & 0.020 & 0.001 \\
Education 3 (Matric) & 0.202 & 0.018 & 0.000 \\
Education 4 (Higher) & 0.538 & 0.019 & 0.000 \\
Education 5 (Mudrassa) & 0.234 & 0.110 & 0.033 \\
Employment 1 (Employee) & 0.501 & 0.060 & 0.000 \\
Employment 2 (Employer) & 0.077 & 0.180 & 0.668 \\
Employment 3 (Self Employed) & 0.362 & 0.068 & 0.000 \\
Employment 5 (Agriculture) & -0.712 & 0.058 & 0.000 \\
Employment 6 (others) & -0.995 & 0.058 & 0.000 \\
Inverse Mills Ratio & -0.460 & 0.038 & \\
R square & 0.157 & Std. Error of Regression & 0.844 \\
Adjusted R square & 0.156 & F-Statistics & $235.768[0.000]$ \\
\hline
\end{tabular}


Model two is the human capital model, in which we used education as a direct human capital variable and age as an indirect variable. Logit model result depicts that primary, middle, and mudrassa education level is negatively related with female labour force participation while, age, age square, family size, matric and higher education level is positively related with female labour force participation.

Table 3: Estimated Probability Model for FLFP by using Human Capital Variables

\begin{tabular}{llll}
\hline Variables & Coefficients & Std. Error & Sig. Level \\
\hline Constant & -1.079 & 0.060 & 0.000 \\
Age & 0.040 & 0.003 & 0.000 \\
Age $^{2}$ & 0.001 & 0.000 & 0.000 \\
Family size $_{\text {Education 1 (Primary) }}$ & 0.016 & 0.002 & 0.000 \\
Education 2 (Middle) & -0.105 & 0.020 & 0.000 \\
Education 3 (Matric) & -0.058 & 0.025 & 0.020 \\
Education 4 (Higher) & 0.143 & 0.021 & 0.000 \\
Education 5 (Mudrassa) & 0.752 & 0.020 & 0.000 \\
Cox \& Snell & 0.642 & 0.154 & 0.000 \\
R square & 0.012 & & \\
\hline
\end{tabular}

OLS result depicts that all the variables are significant, except Education 4 (Higher). Income is increasing function of education which confirms the human capital hypothesis. Higher level of education commands increasingly higher level of income. Again we found that as the level of education increases the returns to each year of education also increase. The age is positively related with personal earnings which show a substantial increase in the wages with each additional year spent. The regression coefficient of inverse Mills ratio is statistically significant which shows a systematic selectivity bias is present due to censoring of nonworking women from the sample.

Table 4: Human Capital Model's Result

\begin{tabular}{llll}
\hline Variables & Coefficients & Std. Error & Sig. Level \\
\hline Constant & 11.041 & 0.255 & 0.000 \\
Age & 0.051 & 0.005 & 0.000 \\
Age $^{2}$ & -0.001 & 0.000 & 0.000 \\
Education 1 (Primary) & 0.190 & 0.019 & 0.000 \\
Education 2 (Middle) & 0.230 & 0.020 & 0.020 \\
Education 3 (Matric) & 0.219 & 0.021 & 0.000 \\
Education 4 (Higher) & -0.052 & 0.070 & 0.455 \\
Education 5 (Mudrassa) & -0.261 & 0.126 & 0.038 \\
Inverse Mills Ratio & -2.801 & 0.209 & 0.000 \\
R square & 0.126 & Std. Error of Regression & 0.8600 \\
Adjusted R square & 0.125 & F-Statistics & $534.592 .000]$ \\
\hline
\end{tabular}

\section{Conclusion and Policy Implications}

The present study is an attempt mainly to analyze the patterns of labor force participation among women. In particular, the study explores the determinants of women's labor force participation decision, their earning patterns. In the present study we focused mainly on households' structures reflecting their socio-economic characteristics. To meet the objectives of the study utilized Multiple Indicator Cluster Survey 2007-08 data. Education is used as a direct human capital variable while; age is a proxy of human capital.

To remove the selectivity bias, the study used Heckman's (1979) two step procedure. Logit model result depicts that household head education, primary, middle, matric \& mudrassa education level negatively related with the decision of FLFP while, decision towards participation is strong if she belonged to urban area, if she is married, if she has higher education, and if she has large family size. By using OLS we estimated the earning function, which depicts that the coefficient of age shows a substantial increase in the wages with 
each additional year spent. The sign of age square is negative which is according to our expectation and implying the concavity of earning function. As the level of education increases the returns to each year of education also increases. In different occupational status females earns more if they are employee, employer or self employed than labourer (a reference category); while female earns less if they belonged to agricultural sector or other sectors than labourer. Married females earn more than others. The respondents' belonged to urban areas earn more than rural respondents. Moreover, household head education and family size are positively significantly related with female earnings

\section{References}

Abe, Y. \& Oishi, A. S. (2008). A Decomposition Analysis of Earnings Inequality for Wives in Japan Graduate School of Economics \& Business Administration Hokkaido University Discussion Paper, Series A, No. 2008-200.

Ahmad, E., \& Hafeez, A. (2007). Labour Supply and Earning Functions of Educated Married Women: A Case Study of Northern Punjab, The Pakistan Development Review, 46(1), 45-62.

Amin, S. (1994). The Poverty-Purdah Trap in Rural Bangladesh. Women. Poverty and Demographic Change, Oaxaca, Mexico, October.

Awan, M. S., \& Hussain, Z. (2007). Returns to Education and Gender Differentials in Wages in Pakistan. The Lahore Journal of Economics, 12(2), 49-68.

Becker, G. S. (1965). A Theory of the Allocation of Time. The Economic Journal, 75(299), 493-517.

Blau, F. D. and Kahn, L. M. (2006). Changes in the Labor Supply Behavior of Married Women: 1980-2000. IZA Discussion Papers 2180.

Ejaz, M. (2007). Determinants of Female Labor Force Participation in Pakistan: An Empirical Analysis of PSLM (2004-05) Micro Data. The Lahore Journal of Economics Special Edition (September 2007), 203235.

Faridi, M. Z., Chaudhry, I. S. \& Anwar, M. S. (2009). The socio economic and demographic determinants of women work participation in Pakistan: Evidence from Bahawalpur District. A Research Journal of South Asian Studies, 24(2), 351-367.

Faridi, M. Z., Chaudhry, I. S., Malik, M. S. (2011). Why Women are Self-Employed? Empirical Evidence from Pakistan. International Journal of Economics and Finance, 3(1), 198-207.

García-Escribano, M. (2004). Does Spousal Labor Smooth Fluctuations in Husbands' Earnings? The Role of Liquidity Constraints IMF Working Paper WP/04/20.

Georgellis, Y. and Wall, H. J. (2005). Gender differences in self-employment. International Review of Applied Economics, 19(3), 321-342.

Heckman, J. (1979). Sample Selection Bias as Specification Error. Econometrica, 47(1), 153-61.

Kazi, S. \& Raza, B. (1986). Household Headed by Women: Income Employment and Household Organisation. The Pakistan Development Review, 27(4), 781-790.

Le Anh, T. (2000). The determinants of Immigrant Self-employment in Australia. International Migration Review, 34(1), 183-214.

Maglad, N. A. (1998). Female labor supply in Sudan. AERC Special Paper 30 African Economic Research Consortium, Nairobi

Mincer, J. (1974). Schooling, Experience and Earnings: New York: National Bureau of Economic Research.

Mincer, J. (1980). Labour Force Participation of Married Women. In Aliech Amsdon (ed.) Economics of Women and Work. Colombia: Penguim Books.

Mincer, J. \& Polachek, S. (1974). Family Investment in Human Capital. Earnings of Women. The Journal of Political Economy, 82(2), 76-108.

Naqvi, Z. F. \& Shahnaz, L. (2004). How do women decide to work in Pakistan? Pakistan Development Review, 41(2), 495-511.

Raaum, O., Eriksson, T., Bratsberg, T., Jäntti, M., Røed, K., Naylor, R. \& Österbacka, E. (2007). Marital Sorting, Household Labor Supply, and Intergenerational Earnings Mobility across Countries Discussion Paper No. IZA DP No. 3037. 